\title{
Van beeldvorming tot sprekende beelden
}

Citation for published version (APA):

Hofman, P. A. M. (2016). Van beeldvorming tot sprekende beelden: Forensische en klinische ontwikkelingen . Maastricht University. https://doi.org/10.26481/spe.20160624ph

Document status and date:

Published: 24/06/2016

DOI:

$10.26481 / \mathrm{spe} .20160624 \mathrm{ph}$

Document Version:

Publisher's PDF, also known as Version of record

\section{Please check the document version of this publication:}

- A submitted manuscript is the version of the article upon submission and before peer-review. There can be important differences between the submitted version and the official published version of record.

People interested in the research are advised to contact the author for the final version of the publication, or visit the DOI to the publisher's website.

- The final author version and the galley proof are versions of the publication after peer review.

- The final published version features the final layout of the paper including the volume, issue and page numbers.

Link to publication

\footnotetext{
General rights rights.

- You may freely distribute the URL identifying the publication in the public portal. please follow below link for the End User Agreement:

www.umlib.nl/taverne-license

Take down policy

If you believe that this document breaches copyright please contact us at:

repository@maastrichtuniversity.nl

providing details and we will investigate your claim.
}

Copyright and moral rights for the publications made accessible in the public portal are retained by the authors and/or other copyright owners and it is a condition of accessing publications that users recognise and abide by the legal requirements associated with these

- Users may download and print one copy of any publication from the public portal for the purpose of private study or research.

- You may not further distribute the material or use it for any profit-making activity or commercial gain

If the publication is distributed under the terms of Article $25 \mathrm{fa}$ of the Dutch Copyright Act, indicated by the "Taverne" license above, 


\section{Maastricht University}

Prof. dr. P.A.M. Hofman

Faculty of Health, Medicine and Life Sciences

\section{Van beeldvorming tot sprekende beelden: forensische en klinische ontwikkelingen}




\section{Van beeldvorming tot sprekende beelden: forensische en klinische ontwikkelingen}

Inaugurele rede uitgesproken bij de ambtsaanvaarding als bijzonder hoogleraar in de Forensische en Postmortale Radiologie, aan de Universiteit Maastricht, door Prof. dr. P.A.M. Hofman op 24 juni 2016.

Geachte mijnheer de Pro-rector Magnificus, leden van het College van Toezicht, leden van de Raad van Bestuur van het MUMC, Decaan en Vice-decaan van de Faculty of Health, Medicine and Life Science, beste collega's, familie en vrienden. Ook ik heet u van harte welkom bij mijn inaugurele rede bij het aanvaarden van mijn leerstoel aan de Universiteit Maastricht.

De Universiteit Maastricht heeft mij benoemd op de leerstoel forensische en postmortale radiologie. Hierbij gaat het om toepassingen van de medische beeldvormende technieken buiten het directe domein van de patiëntenzorg, althans dat wordt door sommige zo gezien. Ik zal $\mathrm{u}$ in mijn oratie meenemen in de voor $\mathrm{u}$ misschien onbekende wereld .

Laat ik u kort de ontwikkelingen van de afgelopen jaren met betrekking tot de forensisch radiologie illustreren middels deze twee kranten artikelen. Het eerste artikel gaat over de moord op een 71 jarige man en in dit artikel uit de Telegraaf van 28 augustus 1979 ziet u de gevleugelde zin staan, ik citeer: "patholoog-anatoom dr. Zeldenrust zal vandaag sectie verrichten". Het tweede artikel komt uit de Volkskrant van 13 februari 2014, 35 jaar later en hier leest u en ik citeer weer:" een scan en sectie maakten duidelijk dat mevrouw Borst aan de gevolgen van haar letsel was overleden. Deze twee kranten knipsels illustreren heel kort de ontwikkelingen in de afgelopen decennia waarbij forensische radiologie zich heeft ontwikkeld tot een volwaardig forensisch medisch onderzoek.

U zult allemaal bekend zijn met röntgenonderzoeken, vanuit uit uw professie, als patiënt en anders zeker vanuit de media. Het is de taak van de klinisch radioloog om het onderzoek te bepalen dat nodig is om de klinische vraag te beantwoorden, samen met de radiologisch laborant het onderzoek uit te voeren en om vervolgens de resultaten te rapporteren aan de aanvragende arts. Deze wijze van werken is de afgelopen eeuw niet veranderd. Iets wat $\mathrm{u}$ misschien niet weet is dat de technieken die binnen de radiologie worden gebruikt om het inwendige van het lichaam in beeld te brengen vanaf het moment van ontdekking ook worden gebruikt buiten het medisch domein. Denkt u hierbij aan de röntgenopname van kunstobjecten of bagage. Maar ook het onderzoek van het menselijk lichaam met behulp van beeldvormende technieken heeft zich niet beperkt tot alleen het medisch behandel domein. Een voorbeeld hiervan is de pedoscoop, een apparaat dat in de jaren vijftig in veel schoenzaken stond en waar de klant zich er van kon vergewissen dat de schoenen ook werkelijk pasten. Ook al in de jaren vijftig was het bekend dat het gebruik röntgenstralen een 
risico met zich meebrengt, maar de kracht van het beeld was zo sterk dat het tot nog jaren heeft geduurd voordat deze apparaten uit de winkels verdwenen.

Maar ook forensisch werden röntgenfoto's gebruikt. Vlak na de ontdekking van de röntgenstralen door Wilhelm Röntgen in 1895 wordt deze nieuwe techniek al gebruikt om de locatie van een kogel op te sporen. Op kerstavond 1895 schiet George Holder de heer Tolson Cunning in het been. Het lukt niet het projectiel te verwijderen. De wond heelt, maar de heer Cunning houdt klachten van zijn been. Op verzoek van de behandelend chirurg wordt op 7 februari 1896 een röntgenfoto van de enkel gemaakt. Het projectiel wordt gelokaliseerd en verwijderd, maar wat interessant is, is dat de röntgenfoto ook als bewijsstuk is gebruikt in de rechtszaak tegen George Holder en uiteindelijk wordt hij veroordeeld tot een gevangenisstraf van 14 jaar [1]. Dit is ook een voorbeeld van een toepassing van beeldvorming van het menselijk lichaam buiten het medisch behandel domein.

Sinds de ontdekking van de Röntgenstralen in 1895 zijn er veel technische ontwikkelingen geweest en ik denk dat er geen ander medisch specialisme is dat zo door technische ontwikkelingen is veranderd dan de radiologie. Aanvankelijk was alleen beeldvorming mogelijk van structuren met een groot natuurlijk contrast met de omgeving zoals de longen en het skelet. Mogelijkheden om contrasten te veranderen door contrastmiddelen toe te dienen enerzijds en een verbetering van de beeldvormende technieken anderzijds hebben er in de loop van de jaren toe geleid dat het nu mogelijk is om afbeeldingen te vervaardigen van alle weefsels van een lichaam en om hierin ook ziekelijke veranderingen te kunnen opsporen. Voor de ontwikkeling van de forensische radiologie en postmortale radiologie is hierbij de technische ontwikkeling van met name de CT van groot belang. Deze technische ontwikkelingen hebben geleid tot een beeldvormende techniek die snel is, beelden geeft met een groot ruimtelijk oplossend vermogen; het is mogelijk om kleine details te zien en waarbij ook niet alleen de botstructuren maar ook de zachte weefsel goed worden afgebeeld.

Radiologische beeldvorming wordt dus al heel lang gebruikt als hulponderzoek bij medisch forensisch onderzoeken. Daarbij werden röntgenfoto's ingezet om botbreuken op te sporen, te zoeken naar kogels en bij te dragen aan de vaststelling van de leeftijd van minderjarigen. Maar pas sinds de technische ontwikkelingen van de CT is het mogelijk een volledig onderzoek te doen van een lichaam en dit heeft er direct toe geleid dat forensische radiologie zich kon ontwikkelen tot een volwaardig forensisch medisch specialisme dat een zelfstandig en onafhankelijk onderzoek doet van een lichaam.

Forensische radiologie wat betekent dat eigenlijk? Forensisch betekent gerechtelijk, betrekking hebbende op het strafrecht en is afgeleid van het Latijns bijvoeglijk naamwoord forensis; betrekking hebbende op het forum, de plaats waar onder andere recht werd gesproken. Forensische radiologie is dus radiologie ten behoeve van het strafrecht.

Een forensisch radioloog is opgeleid tot radioloog en heeft daarmee kennis van medische beeldvormende technieken, kennis van de menselijke anatomie, fysiologie en pathologie en weet op welke wijze ziekelijke processen zichtbaar te maken zijn met beeldvormende 
technieken. Daarnaast beschikt de forensisch radioloog over enige kennis van het straf- en procesrecht en over forensisch onderzoek. De radioloog maakt deel uit van een forensisch radiologisch team dat onderzoek doet aan een lichaam in het kader van een forensisch onderzoek. Daarbij zal het vaak gaan om een overleden persoon, maar ook bij levende personen kan een forensisch radiologisch onderzoek worden verricht.

De grote verschillen tussen klinische radiologie en forensische radiologie zijn de vragen die gesteld worden en de informatie die voor aanvang van het onderzoek beschikbaar is. In de medische praktijk worden medische vragen gesteld, zoals naar de oorzaak van klachten en daarbij is er vaak een heel medisch dossier beschikbaar. Bij een forensisch radiologisch onderzoek is de doodsoorzaak een voor de hand liggende vraag en een meer algemene vraag is of er tekenen zijn van geweldsinwerking op het lichaam. Maar ook de wijze waarop het onderzoek wordt gerapporteerd is totaal anders dan in de klinische praktijk. De taal die in een klinische omgeving wordt gehanteerd is doorspekt met medisch jargon en wordt heel veel medisch kennis verondersteld. Deze medische rapporten zijn voor niet medisch opgeleide personen niet toegankelijk en daarmee voor politie en justitie onbruikbaar. Een forensisch radiologisch rapport moet daarom op een andere wijze worden geschreven.

In Maastricht wordt er sinds 2005 forensisch radiologisch onderzoek verricht en vanaf 2009 heeft dit de vorm gekregen van een structurele dienstverlening aan politie, justitie en het Nederlands Forensisch Instituut. Twee drijvende krachten van het eerste uur hierbij waren Nico Mans en Ingrid Haest die samen dit project gestart zijn. Daarbij is direct het standpunt geweest dat forensische radiologie zich alleen verder kan ontwikkelen wanneer dit vak wordt bedreven door te zake deskundigen en om een forensisch radiologisch onderzoek te doen is juridische, forensische en radiologische deskundigheid noodzakelijk. Dit lijkt voor de hand liggend, maar wanneer beeldvorming wordt ingezet om alleen die vragen te beantwoorden die bijvoorbeeld de patholoog-anatoom niet kan beantwoorden middels een sectie, blijven veel mogelijkheden die beeldvorming biedt onbenut. In veel andere landen worden de CTbeelden beoordeeld door pathologen. Ik vind dat radiologen hierin een prominente rol moeten spelen. Alleen dan schep je de voorwaarden waarmee het maximale uit de gebruikte methode wordt gehaald. Daarnaast is het belangrijk dat de forensisch radioloog ook klinisch werkt; voor de beoordeling van bijvoorbeeld slachtoffers van een geweldsmisdrijf is het belangrijk ook de variatie van het normale te kennen en weten wat de gevolgen van bepaalde letsels kunnen zijn. Maar een radioloog heeft niet alle noodzakelijke deskundigheid en de aanvullende juridische opleiding die een forensisch radioloog heeft gevolgd is onvoldoende om een kwalitatief goed onderzoek te kunnen doen. Er is meer juridische en forensische expertise nodig en de forensisch radiologisch consulent heeft zowel medische, forensische en juridisch kennis en is verantwoordelijk voor een juiste vertaling van de forensische vraag naar een medische vraag en van het medisch antwoord naar een forensisch bruikbaar antwoord. Daarnaast bewaakt de consulent de juridische integriteit van de rapportages.

Dat dit niet triviaal is zal ik u illustreren. Op het moment dat een forensisch radiologisch onderzoek wordt overwogen is er sprake van een mogelijk niet-natuurlijke dood. Vervolgens 
moeten een aantal vragen worden beantwoord; wat is de identiteit van het slachtoffer, wat is de plaats en tijd van overlijden en wat is de doodsoorzaak en welke gebeurtenissen zijn daar aan voorafgegaan. Een forensisch radiologisch onderzoek kan bij de beantwoording van al deze vragen een bijdrage leveren. Op basis van de beschikbare informatie van bijvoorbeeld het onderzoek van de plaats delict en de werkhypothese van de forensische opsporing of forensisch arts kunnen specifieke vragen worden geformuleerd. Maar daarnaast is het van groot belang dat de radioloog deze werkhypothese en specifieke vragen bij aanvang van het onderzoek niet kent om zo een onbevooroordeelde beoordeling te garanderen en een tunnelvisie te voorkomen. De forensisch radiologisch consulent heeft in dit hele proces een sleutelrol. Daarnaast is de bijdrage van de radiodiagnostisch laboranten van groot belang; zonder goede beeldvorming is überhaupt geen onderzoek mogelijk. Door op deze wijze als team te werken wordt het forensisch radiologisch onderzoek een op zich zelf staand forensisch medisch onderzoek. Wat mijn afdelingshoofd prof. Wildberger tijdens zijn oratie zei; "radiologie is een teamspel, Een voor allen, allen voor een" en dat geldt zeker voor forensische radiologie.

Natuurlijk staan we op de schouders van velen. Een naam die niet onvermeld mag blijven is die van Gil Brogdon [2], een Amerikaanse radioloog die het eerste tekstboek over forensische radiologie gepubliceerd heeft in 1998. Sinds de eeuwwisseling is er een toenemende belangstelling voor dit nieuwe vakgebied, zowel zichtbaar aan het aantal publicaties maar zeker zo belangrijk aan de inzet van forensische radiologie bij het onderzoek aan slachtoffers van een mogelijk geweldsmisdrijf en op een aantal plaatsen in de wereld is min of meer gelijktijdig de postmortale beeldvorming met behulp van CT tot ontwikkeling gekomen en in 2011 is de International Society of Forensic Radiology and Imaging opgericht [3].

Zoals gezegd, wordt er vanaf 2009 op een gestructureerde wijze forensisch radiologisch onderzoek verricht in het MUMC+ in samenwerking met Politie van de Regionale Eenheid Limburg, het Openbaar Ministerie en de GGD. In 2013 is er door betrokken partijen een verklaring ondertekend waarin de intentie werd uitgesproken om forensische radiologie verder te ontwikkelen. Aanvankelijk werd er met name gebruikt gemaakt van de mogelijkheden van forensisch radiologisch onderzoek door de Politie in Limburg, maar door onderwijs en voorlichting, verzorgd vanuit het zuiden, werden ook andere Regionale Eenheden zich bewust van de mogelijkheden. Mede op verzoek van de Regionale Eenheid Midden-Nederland is er in 2014 een overeenkomst gesloten met het Meander Medisch Centrum in Amersfoort om daar ook te kunnen scannen, waarbij de beoordeling en rapportage in Maastricht werd gedaan. Om op deze wijze te kunnen werken was het noodzakelijk om een aantal infrastructurele hordes te nemen maar het heeft uiteindelijk geleid tot een grotere beschikbaarheid van forensisch radiologisch onderzoek in Nederland.

Een gebeurtenis die hier niet onvermeld kan blijven is het neerstorten van vlucht MH17 in het oosten van de Oekraïne op 17 juli 2014. Het team uit Maastricht heeft, samen met een 
radioloog uit het $\mathrm{AMC}$ en laboranten van het Meander Medisch Centrum uit Amersfoort, alle slachtoffers van deze ramp forensisch radiologisch onderzocht en heeft zo een bijdrage geleverd aan de identificatie van de slachtoffers en aan het strafrechtelijk onderzoek naar de oorzaak van deze ramp. Op het terrein van de Korporaal Van Oudheusden Kazerne in Hilversum werd binnen 24 uur een forensisch radiologische unit ingericht. Het onderzoeksteam vindt op de beelden lichaamsvreemde materialen en deze minuscule stukjes blijken van cruciaal belang te zijn voor het strafrechtelijk onderzoek [4]. Deze 10 dagen in Hilversum en de rapportage van de beelden in de maanden daarna hebben bij alle betrokkenen een onuitwisbare indruk achtergelaten. Deze gebeurtenis heeft het voor alle betrokkenen ook duidelijk gemaakt dat forensische radiologie het identificatieproces kan veranderen. Samen met het Landelijk Team Forensische Opsporing wordt er nu aan een protocol herziening gewerkt. Deze gebeurtenis heeft er ook toe geleid dat forensische radiologie heel zichtbaar werd voor de Nationale Politie en het Openbaar Ministerie.

Mijn leerstoel betreft naast de forensische radiologie ook de postmortale radiologie. Postmortale radiologie is een sub-specialisme van de radiologie waarbij het radiologisch onderzoek zich richt op een stoffelijk overschot. Het is niet misschien voor iedereen duidelijk, maar direct na het intreden van de dood verandert het lichaam waardoor ook de beelden die radiologische technieken van het lichaam maken een ander aspect hebben. Dit betekent dat er specifieke kennis en ervaring nodig is om deze beelden te kunnen beoordelen. Postmortale radiologie is een onderdeel van forensische radiologie maar ook in de klinische praktijk worden beeldvormende technieken steeds vaker gebruikt, om na het overlijden van een patiënt, inzicht te verkrijgen in de onderliggende processen die tot de dood hebben geleid. Traditioneel heeft radiologie geen rol bij het klinisch postmortale onderzoek en dit was primair de taak van de behandelaar en de patholoog. De laatste jaren neemt de rol van beeldvorming bij het postmortale onderzoek echter toe. Er is een grote overeenkomst tussen forensische radiologie en klinische postmortale radiologie. In beide gevallen gaat het om willen weten wat er werkelijk is gebeurd, niet omdat we de overledenen daar nog mee kunnen helpen maar omdat daarmee de waarheid mogelijk aan het licht komt. Binnen de patiëntenzorg krijgt echter het postmortale onderzoek steeds minder aandacht. Traditioneel bestaat het postmortale onderzoek uit een obductie maar het aantal obducties neemt wereldwijd af en ook in Nederland wordt nog maar bij een klein percentage van de overledenen een obductie verricht. De afgelopen decennia is het percentage van obducties afgenomen met $60 \%$ en op dit moment wordt er bij minder dan $3 \%$ van de overledenen een obductie uitgevoerd [5, 6]. Er is nooit systematisch onderzoek gedaan naar de oorzaken hiervan maar hierbij zullen zowel morele en ethische beweegredenen een rol spelen alsmede de overtuiging dat de doodsoorzaak bekend is. Deze laatste aanname is wellicht nog verdedigbaar wanneer een patiënt na een klinische opname komt te overlijden. Er is dan immers vaak diagnostisch onderzoek verricht. Maar bij mensen die buiten het ziekenhuis overlijden is deze informatie vaak niet beschikbaar. Uit onze eigen ervaring weten we echter dat zelfs bij patiënten die in een ziekenhuis op een intensive care afdeling overlijden, en dat is een afdeling waarbij patiënten uitgebreid onderzocht en gemonitord worden, er bij 
postmortaal onderzoek regelmatig nieuwe en relevante bevindingen worden gedaan die ook de uiteindelijke doodsoorzaak doen veranderen [7]. Voor personen die thuis overlijden is dat in Nederland nooit uitgebreid onderzocht, maar er mag worden aangenomen dat hierbij veel vaker de werkelijk doodsoorzaak niet wordt vastgesteld. Uit onderzoek blijkt dat vaak de doodsoorzaak verandert na uitgebreid postmortaal onderzoek zoals een obductie of postmortaal radiologisch onderzoek [8].

Het is natuurlijk belangrijk om de doodsoorzaak vast te stellen. Dit is van belang voor familie en nabestaande. Voor de behandelende artsen is het eveneens van belang te weten waaraan een patiënt is overleden, maar ook of er naast de bekende aandoening, andere ziekelijke veranderingen waren aan het lichaam. Dit is in feite het laatste moment waarop de klinische diagnose getoetst kan worden aan de "werkelijkheid". Dit is belangrijk voor de kwaliteitsbewaking van de zorg en voor de opleiding. Daarnaast komt de doodsoorzaak in de registratie van het Centraal Bureau voor de Statistiek en hierop worden beleidsbeslissingen genomen door de overheid. Er zijn dus voldoende argumenten om aandacht te besteden aan overlijdens onderzoek.

Onze eigen ervaring heeft laten zien dat postmortaal radiologisch onderzoek de kwaliteit van het postmortale onderzoek als geheel doet verbeteren. Radiologisch onderzoek zal nooit de klassieke obductie vervangen. Maar wanneer een uitwendig onderzoek van een overledene wordt aangevuld met een radiologisch onderzoek, eventueel in combinatie met minimaal invasieve technieken zoals histologisch biopten van verdachte gebieden of een angiografie, kan de doodsoorzaak met een veel grotere zekerheid worden vastgesteld dan alleen met een uitwendig onderzoek. Een toxicologisch onderzoek van het lichaam kan dit onderzoek verder complementeren. Het op deze wijze onderzoeken van een lichaam komt ook tegemoet aan de wens van nabestaande(n) om de integriteit van het lichaam zoveel mogelijk intact te laten en zijn er veel minder ethische en religieuze bezwaren tegen postmortaal radiologisch onderzoek dan tegen een obductie.

Zowel forensisch radiologisch als klinisch postmortaal onderzoek produceren beelden en plaatjes. Beelden spelen een steeds grotere rol in onze maatschappij. Taal is de drager van onze cultuur geweest in de vorm van verhalen en vanaf circa drieduizend voor Christus in de vorm van het geschreven woord. Beelden zijn er altijd geweest, maar waren beperkt beschikbaar en beperkt toegankelijk. De laatste decennia, gedreven door de technologische ontwikkelingen zijn beelden steeds belangrijker geworden om kennis en cultuur over te dragen; er is een overgang van een woordcultuur naar een beeldcultuur. Deze ontwikkeling is al ingezet met de opkomst van fotografie eind 19e eeuw en al in 1911 zei de Amerikaanse journalist en hoofdredacteur van de New York Journal, Arther Brisbane, tijdens een overleg met zijn journalisten: "Use a picture. It's worth a thousand words." Beelden spelen een steeds grotere rol in de samenleving. Velen van ons dragen iedere dag een camera bij zich en het is heel gewoon om een digitaal archief op zak te hebben van alle belevenissen van de afgelopen tijd. Ook mensen met medische klachten vragen om beeldvorming. In het afscheidscollege 
van Prof. Van Engelshoven, een van mijn leermeesters en oud afdelingshoofd, betoogde hij dat wie bang is niet wil wachten en direct een beeldvormend onderzoek wil om klachten te objectiveren of ter geruststelling. Daarbij speelt het letterlijk zichtbaar maken van afwijkingen een belangrijke rol. In de medische praktijk is het sinds de digitalisering van radiologie afdelingen heel gebruikelijk om bij ieder multidisciplinair overleg gebruik te maken van beelden. Een belangrijke taak van de radioloog is zorgdragen dat zijn bevindingen op de juiste manier worden geïnterpreteerd. Het belang van dit overleg werd door mijn mentor en opleider neuroradiologie Prof. Wilmink op treffende wijze geformuleerd in zijn afscheidscollege, ik citeer: " $\mathrm{Na}$ de uitvoering van het onderzoek vindt schriftelijke verslaglegging plaats. Minstens even belangrijk is echter vaak het mondelinge overleg met de verwijzende clinicus, gezeten voor het beeldscherm, waarbij nuances kunnen worden aangebracht, aanvullende vragen gesteld en nieuwe diagnostische opties overwogen. Zó behoort ons vak uitgeoefend te worden, en wanneer radiologen zich laten reduceren tot 'verslaghengsten' komt ons vak terecht in een marginale en kwetsbare positie'. Dit geldt ook voor een forensisch radiologisch onderzoek. Direct na het maken van de scan worden de beelden beoordeeld en naast een geschreven rapport is er direct overleg met het forensisch onderzoeksteam waarbij ook beelden worden gebruikt om duidelijk te maken wat de bevindingen zijn. In het uitgebreide rapport dat op verzoek van de officier van justitie wordt gemaakt, worden ook veel beelden gebruikt om het geschreven woord te ondersteunen. In onze praktijk erkennen we de waarde van beelden en weten we dat alleen een rapportage in woorden niet de volledige waarheid overbrengt. Ons rechtssysteem is echter een woordcultuur en beelden worden weinig gebruikt. Beelden kunnen echter op een heel heldere wijze feiten weergeven en patronen laten zien. In principe kan dit ook in woorden, maar wanneer verschillende mensen wordt gevraagd een schets te maken op basis van een beschrijving van een situatie is de kans groot dat er verschillende schetsen worden gemaakt. Dit geldt ook voor een letselbeschrijving van een lichaam. Wanneer een letselbeschrijving wordt geciteerd tijdens een rechtszitting zullen de toehoorders, en de belangrijkste zijn de rechters, zich een beeld vormen van de letsels, gebaseerd op een individuele interpretatie van het citaat. Deze interpretatie is afhankelijk van de ervaring, de kennis en het referentiekader van de toehoorder. Ik zal u dat illustreren aan de hand van het volgende krantenartikel uit de Argus van 13 maart 1948. In het artikel wordt een beschrijving gegeven van de Dutchman; hij heeft kort haar en een opvallend grote neus. Afhankelijk van uw referentiekader en kennis past het beeld dat $\mathrm{u}$ in uw gedachten heeft geschetst bij een man met kort haar en een grote neus of bij een neusaap, ook wel een Dutchman genoemd. De bewoners van Borneo, waar deze apen leven, moesten gelijk aan de neusaap denken toen zij voor het eerst Nederlanders zagen. Volgens hen hebben wij net zulke blonde haren, dikke buiken en grote neuzen. Het is belangrijk om zich te realiseren dat we allemaal voor onszelf een beeld schetsen wanneer we een beschrijving krijgen en dat dit beeld afhankelijk is van onze kennis en referentiekader. Wanneer echter dat beeld niet alleen wordt beschreven maar ook beschikbaar is, schept dat de mogelijkheid tot een gemeenschappelijk vertrekpunt. 
Terug naar de forensische radiologie. Beelden kunnen dus een helder overzicht geven van bijvoorbeeld de letsels van een slachtoffer van een geweldsmisdrijf. Traditioneel worden hiervoor foto's van het slachtoffer gebruikt. Dit brengt echter een zeker risico met zich mee. Zowel taal als beelden kunnen feitelijkheden overbrengen maar hebben ook een emotionele connotatie. Beelden hebben een mimetische component, het zo getrouw mogelijk weergeven van de feitelijkheden, maar beelden hebben ook een diëgetische component; hierin liggen waarde, emoties en interpretaties besloten [9]. Binnen de rechtsgang is men terecht zeer beducht voor deze diëgetische component van beelden. Deze component kan immers onbewust een strafverzwarende invloed hebben; het ziet er immers verschrikkelijk uit. Hier kan forensische radiologie een oplossing bieden. Door de CT beelden op een andere manier te ordenen en weer te geven kunnen letsels en letselpatronen zichtbaar worden gemaakt zonder een fotorealistische weergave van het slachtoffer. Hierbij kan door middel van een ander kleurpalet en selectie van bepaalde lichaamsstructuren een meer afstandelijk beeld worden gemaakt van het slachtoffer, waarbij de feitelijkheden duidelijk zichtbaar zijn, maar waarbij de potentieel emotionele component tot een minimum wordt beperkt. Hiermee is een objectief en reproduceerbare weergave van de letsels van een slachtoffer beschikbaar. Dit is vanuit historisch oogpunt ook interessant want in "The Emergence of the Silent Witness: The Legal and Medical Reception of X-rays in the USA" beschrijft Golan dat al aan het einde van de 19e eeuw, radiologische beeldvorming werd gezien als een "new class of machine-made testimonies" dat visueel en objectief bewijs gaf, in dat geval bij medische aansprakelijkheidszaken [10].

Beeldvorming kan nog een stap verder worden gebracht. Samen met de Nationale Politie en het Nederlands Forensisch Instituut is een methode ontwikkeld, waarin alle resultaten van een forensisch onderzoek bij een dodelijk schietincident worden samengebracht in een 3D model, dat vervolgens gebruikt kan worden om scenario's en verklaringen te toetsen en dat uiteindelijk ook ter rechtszitting kan worden gebruikt. Ook hierbij is het streven een gemeenschappelijk uitgangspunt te bieden en niet te vertrouwen op de verschillende en individuele reconstructies op basis van diverse rapporten.

De Gezondheidsraad constateert in haar rapport: "Forensische geneeskunde ontleed; naar een volwaardige plaats voor een bijzondere discipline", uitgebracht in 2013, dat er knelpunten zijn in de forensisch-medische beroeps- uitoefening en dat er aanwijzingen zijn dat niet-natuurlijk overlijden en letsels ontstaan door mishandeling niet altijd goed worden herkend en dat daardoor frequent bewijsmateriaal verloren gaat [11]. De commissie stelt in haar advies vast dat de forensische geneeskunde in ons land niet de positie inneemt die past bij haar belangrijke taken en ze geeft vervolgens een aantal adviezen waarvan ik er twee noem. Forensisch geneeskundige basisvaardigheden moeten een volwaardige plaats krijgen in het basiscurriculum geneeskunde en er wordt geadviseerd een academische werkplaats forensische geneeskunde in de brede zin op te zetten om de kwaliteit van het forensisch medisch onderzoek te verbeteren. De Universiteit Maastricht heeft dit advies van de Gezondheidsraad ter harte genomen en biedt forensische geneeskunde in de brede zin een 
academische werkplaats. Recent heeft een prof. Kubat hier haar oratie uitgesproken als hoogleraar forensische pathologie, vandaag is het mijn beurt en het is de verwachting dat het daar niet bij blijft. Ik sluit me ook van harte aan bij het initiatief van Prof. Mols om te komen tot een interfacultair forensisch instituut binnen de Universiteit Maastricht. De forensische en postmortale radiologie hebben nu een stevig fundament in Maastricht, maar alleen een fundament is wat mager. Waar wil ik heen met de forensische en postmortale radiologie?

Op dit moment wordt er in Nederland weinig postmortaal onderzoek gedaan, zoals ik u al verteld heb, wordt bij minder dan $3 \%$ van de mensen die in Nederland overlijden een uitgebreid postmortaal onderzoek verricht en ook wanneer een gemeentelijke lijkschouwer of forensisch arts betrokken is bij het overlijdensonderzoek wordt er maar circa 3\% van de gevallen een obductie verricht. Ik vind dat er in Nederland te weinig aandacht wordt geschonken aan het overlijdensonderzoek en ik heb u meerdere redenen genoemd waarom dit problematisch is. In mijn visie speelt beeldvorming een belangrijke rol in kwalitatief verbeteren van het overlijdensonderzoek, omdat het niet of minimaal invasie is, snel beschikbaar en kosten effectief is. Tevens wordt er een permanent archief aangelegd dat altijd beschikbaar blijft. Daarnaast is de drempel om postmortaal radiologisch onderzoek te verrichten lager dan voor een obductie omdat er minder ethische en religieuze bezwaren zijn. Klinisch postmortaal en forensische radiologisch onderzoek moet dus veel vaker worden toegepast. Maar om dit te kunnen verwezenlijken zijn wel en aantal zaken nodig.

Forensische radiologisch onderzoek moet als onafhankelijk deskundigheidsgebied een plaats krijgen binnen het medisch forensisch onderzoek in Nederland en daarom moeten ook de verschillende deskundigheden geregistreerd worden in het Nederlands Register Gerechtelijk Deskundigen. Samen met het Nederlands Forensisch Instituut, de Nationale Politie en het Openbaar Ministerie is een plan ontwikkeld om forensische radiologie beschikbaar te maken voor de gehele Nationale Politie, dus in alle regio's van het land. Dit wordt georganiseerd binnen het netwerk met een aantal samenwerkende ziekenhuizen, radiologen, consulten en laboranten, vanuit een nationaal expertise centrum in Maastricht.

Op dit moment wordt forensisch radiologisch onderzoek met name ingezet bij onderzoek van overleden slachtoffers van een geweldsmisdrijf. Overleden verkeersslachtoffers, in Nederland kwamen in 2015621 mensen om in het verkeer [12], worden in Nederland bijna niet onderzocht. Er wordt geen onderzoek ingesteld naar een medische oorzaak van het ongeval en er wordt weinig medisch onderzoek gedaan naar ongeval mechanisme. Vanuit het perspectief van veiligheid kan het van belang zijn te weten waaraan een slachtoffer van een verkeersongeval is overleden. Mogelijk brengt dit risicofactoren aan het licht. Het is bijvoorbeeld opvallend dat ondanks de sterke afname van het aantal verkeersdoden de laatste jaren, deze afname onder fietser en bromfietsers achter blijft. Onderzoek van de slachtoffers kan aanleiding geven tot specifieke maatregelen om de veiligheid te verbeteren. Samen met 
de verkeer-ongevallenanalyse, de VOA, van de Nationale Politie gaan we hier meer aandacht voor vragen. Maar in het algemeen moet beeldvorming meer worden ingezet bij het overlijdensonderzoek door een forensisch arts om beter onderbouwd tot de overtuiging te komen dat er sprake is van een natuurlijk of niet-natuurlijk overlijden.

Maar wat buiten het ziekenhuis nog niet gebeurt, uitgebreid postmortaal onderzoek, gebeurt in de kliniek evenmin. Daarom wil ik klinische postmortale radiologie verder ontwikkelen tot een klinisch kwaliteitsinstrument waarbij het, in het MUMC, wordt ingezet als aanvulling op en als alternatief voor een obductie, waarbij het streven blijft beide onderzoeken te doen. In samenwerking met de afdeling Interne Geneeskunde van het MUMC wordt dit nu vorm gegeven. We willen hiermee ook een bijdrage leveren aan het werk van de Commissie Onderzoek Overleden Patiënten van het MUMC en daarmee aan de kwaliteit van de zorg.

Om deze visie te kunnen verwezenlijken is het ook nodig om de wetenschappelijke basis van de forensische en postmortale radiologie te verbreden. Soms lijkt er onduidelijkheid over de diagnostische waarde, over de sensitiviteit en specificiteit van beeldvorming daar waar het gaat om het vast stellen van bepaalde afwijkingen. Heel vaak echter gaat het om onbekendheid met wat met radiologie mogelijk is en klinisch allang wordt toegepast. Het ligt bijvoorbeeld voor de hand dat een CT van het lichaam van een overleden slachtoffer van een schietincident belangrijke informatie kan leveren over de letsels van het slachtoffer. Dit is immers iets wat in de klinische praktijk ook gebeurt. Voor een forensisch onderzoek zijn er ook nog andere vragen die relevant zijn zoals; de richting van een traject door het lichaam, waar is het projectiel het lichaam binnen gedrongen en waar heeft het projectiel het lichaam verlaten en wat is de hoek van het traject. Radiologische beelden lenen zich bij uitstek voor het beantwoorden van deze vragen en Rob van Kan, een promovendus bij onze groep, doet hier onderzoek naar en zijn bevinding laten zien dat het radiologisch onderzoek bij schietincidenten van groot belang is en een grote diagnostische waarde heeft [13]. Maar dit is slechts één van de toepassingsgebied van forensische en postmortale radiologie. Ook ligt er de uitdaging om middels beeldvorming doodsoorzaken en letsels zichtbaar te maken waar het klassieke postmortale onderzoek moeite mee heeft. Als voorbeeld noem ik u het acute hartinfarct. Een betrouwbare methode om postmortaal een acuut infarct aan te tonen is er nog niet en beeldvorming biedt hier mogelijk een oplossing.

En dan als laatste, maar zeker niet als minste, is het van belang om binnen het medisch curriculum meer aandacht te besteden aan forensische geneeskunde in het algemeen en aan forensische radiologie in het bijzonder. $\mathrm{Nu}$ komt dit alleen in het keuze-onderwijs aan de orde. Ook bij andere forensische en juridische opleidingen moet er meer aandacht komen voor forensische geneeskunde en forensische radiologie. Denk daarbij aan de Masteropleiding Forensica, Criminologie en Rechtspleging van Universiteit Maastricht. 
Ik vind dat postmortale radiologisch beeldvorming meer moet worden ingezet, om door middel van sprekende beelden een bijdrage te leveren aan de waarheidsvinding, zowel klinisch als forensisch en dat is mijn missie voor de komende jaren.

Ik wil graag afsluiten met een dankwoord.

Het is de verdienste van velen dat ik hier nu sta, maar ik kan niet iedereen persoonlijk bedanken. Een aantal mensen wil ik toch noemen.

Als eerste wil ik Professor van Engelshoven bedanken, beste Jos, jij als afdelingshoofd hebt het goed gevonden dat we de CT-scanners voor postmortaal onderzoek gingen gebruiken. Dat heeft het allemaal mogelijk gemaakt.

Dat forensische radiologie vervolgens tot bloei heeft kunnen komen is te danken aan de visie van Professor Wildberger en dhr. van den Broek. Beste Joachim en Guido, jullie als bestuurders van onze afdeling hebben de forensische radiologie een plaats gegeven binnen de afdeling, zonder jullie support was het niet gelukt. Ik dank de Raad van Bestuur van het MUMC, de decaan Professor Scherpbier en de vice-decaan Professor De Vries voor het omarmen en ondersteunen van deze nieuwe ontwikkeling en dank hen voor het instellen van deze leerstoel. Ik realiseer me terdege dat het niet vanzelfsprekend is dat we deze ruimte hebben gekregen en ik vind het elke dag opnieuw weer een voorrecht om in het MUMC+ te mogen werken.

Professor Wilmink, best Jan, dank voor alle uren achter de lichtkast, van jou heb ik neuroradiologie geleerd en het belang van het demonstreren van je bevindingen, in de vorm van klinische besprekingen, maar ook in de vorm van onderwijs. Je stuurde me op pad met dozen vol dia's om in het land onderwijs te geven en dan niet 30 minuten maar een hele dag. Ik heb veel van je geleerd.

Ik heb de afgelopen jaren veel samen gewerkt met Professor Backes en dr. Jansen, we hebben samen met name epilepsie onderzoek gedaan. Beste Walter en Jaap, ik wil jullie bedanken voor de heel prettige samenwerking en ik hoop dat we ook in de toekomst blijven samenwerken.

Ik dank mijn collega's radiologen, ik realiseer me eens te meer dat we een heel goed team hebben en dat we door de jaren heen al heel wat stormen hebben doorstaan, ik dank jullie voor jullie collegialiteit en vriendschap.

Ik bedank de laboranten van de afdeling radiologie, zonder jullie was er überhaupt niets en jullie zijn altijd bereid mee te denken en mee te werken, dank daarvoor. Het secretariaat en de administratie van de afdeling, ik probeer niet verstrooid te zijn, maar zonder jullie hulp gaat het niet goed, dank voor de prettige samenwerking. 
Ik wil de collega's van het NFI bedanken, we weten elkaar steeds beter te vinden en ik vertrouw er op dat we de prettige samenwerking verder zullen uitbouwen.

De collega's van de forensisch opsporing van de Politie Regionale Eenheid Limburg en Midden-Nederland en van de Landelijke Eenheid. Samen met jullie zijn we begonnen, ik wil jullie bedanken voor de prettige samenwerking, jullie vertrouwen, steun en visie. Ik wil met name Toine Voeten, Wiebe van Lohuizen, Mette Rurup en Rob van Kan bedanken.

De forensisch Officiëren van Justitie van Parket Limburg, mr. Mattheijs en mr. Janssen, beste Dave en Bas, dank voor de prettige samenwerking. De forensisch artsen van de GGD Limburg en in het bijzonder Roland Van Hooren, samen met jullie hebben we het forensisch medisch onderzoek uitgebouwd, dank voor de prettige samenwerking.

De collega's van de unit forensische radiologie wil ik bedanken, de radiologen uit het team, de laboranten uit het MUMC en het Meander Ziekenhuis en de forensisch radiologisch consulenten. Toen we begonnen was het pionieren en jullie hebben daar allemaal in geïnvesteerd en samen hebben we het gebracht tot waar het nu staat. Jeroen Kroll en Ingrid Haest zijn de ruggengraat van de unit, dank voor jullie doorzettingsvermogen en steun.

Ik wil u allen danken voor uw aanwezigheid en in het bijzonder onze gasten van down-under, thank you Tonia for traveling so far to celebrate with us today. Thank you dr. Chris O'Donnell for coming to Maastricht to attend my inauguration and sharing your thoughts on forensic radiology with us.

Waar werk maar werk is, het allerbelangrijkste zijn toch jullie, Ingrid, Zelie en Bart.

Bart en Zelie, ik voel me bevoorrecht vader te mogen zijn van twee zo bijzondere kinderen. Jullie hebben je ontwikkeld tot oprechte en onafhankelijk denkende personen en ik heb er alle vertrouwen in dat jullie je weg in het leven zullen vinden. Aan jullie is de toekomst. Jullie hebben de ontwikkeling van de forensische radiologie van nabijheid meegemaakt als een uit de hand gelopen hobby van jullie ouders en ondanks onze frequente afwezigheid was er nooit een onvertogen woord.

Ingrid, er zijn geen woorden voor wat ik je wil zeggen. We hebben samen al heel veel meegemaakt en bereikt en ik wil je danken voor je liefde, je onvoorwaardelijke steun, je visie en je drive. Jou lukt het iedere keer weer alles met elkaar te verbinden. Dat we samen nog heel veel mogen meemaken en genieten van het leven.

Ik heb gezegd. 
Referenties

1. Cox J, Kirkpatrick RC. The New Photography: with Report of a Case in which a Bullet was Photographed in the Leg. 1896.

2. Brogdon BG. Forensic Radiology. CRC Press; 1998.

3. History of the ISFRI [Internet]. [1 juli 2016] http://www.isfri.org/about-us/history/

4. MH17: zes aspecten van het strafrechtelijk onderzoek toegelicht [Internet]. Forensisch onderzoek naar brokstukken. [1 juli 2016] https://www.om.nl/mh17-ezine-juni2016/4forensisch-onderzoek.html

5. Kuijpers CCHJ, Fronczek J, van de Goot FRW, Niessen HWM, van Diest PJ, Jiwa M. The value of autopsies in the era of high-tech medicine: discrepant findings persist. J Clin Pathol. 2014 May 17;67(6):512-9.

6. Kretzschmar H. Brain banking: opportunities, challenges and meaning for the future. Nat Rev Neurosci. 2009 Jan;10(1):70-8.

7. Bakers FC, Hofman PAM, Kroll J, Prevos B, de Vries B, Latten B, et al. Post-mortem CT imaging with biopsies as an alternative to autopsy in the diagnosis of cause of death in the intensive care unit: initial observations. 2014. p. Oo9.06.

8. Roosen J, Frans E, Wilmer A, Knockaert DC, Bobbaers H. Comparison of premortem clinical diagnoses in critically iII patients and subsequent autopsy findings. Mayo Clin Proc. 2000 Jun;75(6):562-7.

9. van den Hoven PJ. Beeldgebruik in de rechtszaal: Van 'kijk zelf maar' naar "laat maar zien.” Nederlands Juristenblad; 2012. 5 p.

10. The emergence of the silent witness: the legal and medical reception of X-rays in the USA. 2004 Aug;34(4):469-99.

11. Forensische geneeskunde ontleed. Naar een volwaardige plaats voor een bijzondere discipline. Den Haag 2013: Gezondheidsraad.

12. Aantal verkeersdoden stijgt naar 621 in 2015. [1 juli 2016] https://www.cbs.nl/nlnl/nieuws/2016/16/aantal-verkeersdoden-stijgt-naar-621-in-2015

13. van Kan RAT, Kubat B, Haest IIH, van Lohuizen W, Kroll J, Lahaye MJ, et al. Comparison between radiologist and pathologist in determining trajectories in gunshot victims. Journal of Forensic Radiology and Imaging. (2):96. 